\title{
Thallium poisoning: Clinical observations through two outbreaks in Basrah
}

\section{Talyum zehirlenmesi: Basra'daki iki salgın nedeniyle klinik gözlemler}

\author{
Khalil I. Al-Hamdi ${ }^{1}$, Ahmed A. Al-Mohammadi ${ }^{2}$ \\ ${ }^{1}$ Department of Dermatology-Venereology, College of Medicine-University of Basrah, Iraq \\ ${ }^{2}$ Department of Dermatology-Venereology, Basrah Teaching Hospital, Iraq
}

\begin{abstract}
Objectives: Thallium is one of the most suitable agents for criminal poisoning of human as it is tasteless and odorless. The aim of this study was to report clinical features of thallium poisoning in two outbreaks.

Materials and methods: This case descriptive study was conducted in Basrah Teaching Hospital from January 2009 to February 2010, where a total of 32 patients with thallium poisoning were enrolled. At the first outbreak, poisoning occurred due to ingestion of cake, while the second outbreak was due to accidental ingestion of rat poisons. A detailed history was taken and complete clinical examination was performed. Thallium in urine was measured using the colorimetric method and was found as positive in all patients.
\end{abstract}

Results: Thirty two patients were evaluated. The first outbreak included 17 patients (mean age 24 years), and the second outbreak included 15 patients (mean age15 years). Among both outbreaks the dermatological findings were mainly hair loss in diffuse and patchy pattern affected the scalp and limbs. Also dusky ecchymotic red dermatitis like rash was observed on the face, especially perioral region and dorsum of hands and legs. Neurologic manifestations, mainly of peripheral neuropathy, were seen in $50 \%$ patients of the second group. Patients erroneously had received zinc-sulphate before correct diagnosis. Thirty patients were improved and two died.

Conclusion: Outbreak of thallium poisoning may be result of accidental ingestion or criminal purposes. It gives characteristic cutaneous, neurological and psychological features that can lead to the definite diagnosis. J Clin Exp Invest 2010; 2 (1): 11-15

Key words: Thallium poisoning, clinical findings, diagnosis, outbreak, Basrah.

\section{ÖZET}

Amaç: Talyum tatsız ve kokusuz olduğu için, kötü amaçlı zehirlemeler için en uygun maddelerden birisidir. Bu çalışamını amacı iki ayrı salgında ortaya çıkan talyum zehirlenmesi vakalarının klinik özelliklerini sunmaktır.

Gereç ve yöntem: Bu tanımlayıcı vaka çalışmasına Ocak 2009- Şubat 2010 tarihleri arasında Basra Eğitim Hastanesinde izlenen toplam 32 talyum zehirlenmeli hasta dahil edilmiştir. İlk salgında kek yeme sonucu, ikinci salgında fare zehiri yeme sonucu zehirlenmeler oluştu. Tüm hastalardan ayrıntılı öykü alındı ve tam bir fizik muayene yapıldı. İdrarda talyum kolorimetrik yöntemle arandı ve tüm hastalarda pozitif bulundu.

Bulgular: Toplam 32 hasta incelendi. İlk salgında yaş ortalaması 24 yıl olan 17 hasta, ikinci salgında yaş ortalaması 15 yıl olan 15 hasta izlendi. Her iki salgında da ana dermatolojik bulgu, saçlı deri ve ekstremiteleri tutan yamalı veya diffüz tarzda saç ve kıl kaybı idi. İlave olarak yüzde özellikle ağız etrafında ve el ve ayak sırtlarında kirli kırmızı ekimotik dermatit benzeri lezyonlar gözlendi. İlk salgında nörolojik bulgular oluşmadı fakat ikinci salgında hastaların \%50'sinde başlıca periferik nöropati şeklinde nörolojik bulgular gözlendi. Hastaların çoğu yanlış olarak çinko eksikliği tanısıyla oral çinko-sulfat tedavisi almıştı. Hastalardan 30'u iyileşti, ikisi öldü.

Sonuç: Talyum zehirlenmesi kazara alım veya suç amaçlı oluşabilir. Talyum zehirlenmesi karakteristik cilt, nörolojik ve psikolojik belirtilere yol açarak kesin tanı koydurur. Klin Deney Ar Derg 2010; 2 (1): 11-15

Anahtar kelimeler: Talyum zehirlenmesi, klinik bulgular, tanı, salgın, Basra

Yazışma Adresi / Correspondence: Dr. Khalil I. Al-Hamdi, Department of Dermatology and Venereology

College of Medicine-University of Basrah, Basrah, Iraq E-mail: khalil_hamdi2003@yahoo.com

Geliș Tarihi / Received: 20.01.2011, Kabul Tarihi / Accepted: 12.02.2011

Copyright $\odot$ Klinik ve Deneysel Araștırmalar Dergisi 2011, Her hakkı saklıdır / All rights reserved 


\section{INTRODUCTION}

Thallium is a heavy metal that has qualities of a perfect criminal poison. Its salts are tasteless, colorless and odorless, that dissolve completely in liquids, which are rapidly absorbed, and defy detection on routine toxicological screens. Thallium has been the agent of choice in several criminal poisonings, and thallium levels in normal human and animals are $<1 \mathrm{ppb}$ in blood and urine, and $<10$ ppb in tissues. ${ }^{1-3}$

Elimination half-life of thallium is long, due to its large distribution volume. The estimated halflife in humans is reported between 1-3 days after low doses and between 1-1,7 days under clinical therapy after ingestion or exposure by a possible lethal dose. Other groups have reported an elimination half-life between 8-30 days. Minimum lethal dose $\left(\mathrm{LDL}_{0}\right)$ of thallium in humans is also highly variable. Average lethal dose for thallium sulfate has been reported to range from $10-15 \mathrm{mg} / \mathrm{kg}{ }^{4}$

Thallium poisonings are generally due to ingestion of the salts, but cases of inhalation of dusts or fumes from smelting, skin absorption and even from sniffing contaminated cocaine have been reported. ${ }^{5,6}$ It is used in the manufacture of electronic components, optical lenses, semiconductor materials, alloys, gamma radiation detection equipment, imitation jewelry, artist's paints, low temperature thermometers, and green fireworks. ${ }^{5}$

In some parts of the world it is still used for killing rodents and this may lead to inadvertent ingestion by humans. ${ }^{7}$ Thallium poisoning is rare in Western societies. It has occasionally been the tool for murder. ${ }^{8}$

In October 1988, five of seven members of a Florida family were poisoned with thallium, constituting the largest outbreak of acute thallium poisoning in the United States since thallium was banned as a rodenticide in $1972 .^{2}$

An outbreak of thallium poisoning was reported in Baghdad in February 2008 where mem- bers of Iraqi Air Force Club and some of their children were poisoned by cake laced with thallium. Two of the children died. ${ }^{9}$

Its toxic effect is due to its ability to inhibit a number of intracellular potassium-mediated processes and legends formation with protein sulfhydril groups, inhibition of cellular respiration, interaction with riboflavin and riboflavin-based cofactors, and distribution of calcium homeostasis. ${ }^{1,4}$

The diagnosis of thallium poisoning is not very easy and requires chemical analysis to confirm it. Emsley mentioned that a person in the UK poisoned eight people and two of them died.1 Demonstration of the presence of thallium in urine is the best diagnostic procedure available. ${ }^{4}$

Thallium remains a means of criminal poisoning and should be considered in any patient with a rapidly progressing peripheral neuropathy with or without alopecia. ${ }^{8}$

Short-term exposure to thallium may induce hair loss, skin lesions, and damage to the nervous system. ${ }^{4,10-13}$ The clinical features of short-term thallium intoxication include gastrointestinal symptoms of nausea, vomiting, stomatitis, and diarrhea, followed by severe painful dysesthesia and paraesthesia in the distal limbs, erythematous rashes in the cheeks and perioral region, and hyperkeratosis with loss of hair in sub acute stage. ${ }^{2,3}$ In the long-term, complete hair loss and severe polyneuropathy have been noted. The severity of dermatological pictures is supposed to be related to the severity of thallium intoxication. ${ }^{13}$

The combination of rapid, diffuse alopecia, with neurologic and gastrointestinal disturbance is pathognomonic for thallium toxicity. The hair mount, showing a tapered or bayonet anagen hair with black pigmentation at the base, which may be highly diagnostic before the onset of alopecia. ${ }^{11}$

The present work is designed to reporting two outbreaks of thallium poisoning in Basrah, south of Iraq. 


\section{MATERIALS AND METHODS}

This case descriptive study that was conducted at the Department of Dermatology-Basrah Teaching Hospital from January 2009 to February 2010, where a total of thirty two patients with thallium poisoning were seen during two outbreaks, the first outbreak included 17 patients out of 32 who were seen at January 2009 while the second outbreak included 15 patients out of 32 who were seen at February 2010.

A detailed history was done regarding the following points: age, sex, mode of intake, patient's presenting complaints and time of onset. Full dermatological examination was performed looking for skin manifestation and other systemic involvement. Thallium in urine has been measured in the poisoning consultation center using the colorimetric method and was positive in all of patients.

The ethical approval of the scientific committee of the local Scientific Council of Dermatology \& Venereology-Iraqi Board for Medical Specializations, was taken.

\section{RESULTS}

Thirty two patients with thallium poisoning were evaluated in two outbreaks. The first outbreak (group 1) including 17 patients, 13 males and 4 females, their ages ranged from 11-33 years with a mean of 24 years, all those patients gave history of eating cakes laced with thallium.

Whereas the second outbreak (group 2) including 15 patients, 8 males and 7 females, whose ages ranged from 5-30 years with a mean of 15 years, all those patients gave history of accidental ingestion of rat poison.

All patients of the first outbreak were presented after the ingestion of cakes that laced with thallium where developed immediate onset sign and symptoms of thallium intoxication including: nausea, vomiting and diarrhea and within two weeks they developed skin manifestations mainly severe hair loss in diffuse and patchy forms of anagen type, affecting mainly scalp and body hair but with out any neurological manifestations.

While in the second group all patients presented after accidental ingestion of rat poison where they developed sign and symptoms of thallium intoxication including: nausea, vomiting and diarrhea, followed in $50 \%$ of them by mental and peripheral neurological complaints and within two weeks all patient of this group developed skin manifestations mainly severe hair loss in diffuse and patchy forms of anagen type, affecting mainly scalp and body hair.

\section{Clinical findings including dermatological data}

Anagen hair loss that was obvious in all the patients of both groups (Figure 1), it was started in the second and third week, as diffuse or patchy hair loss involving mainly the scalp and the lower limbs. The affected hair was either broken at the surface of the skin in black dots like patterns or diffusely lost, presenting as diffuse hair thinning or as a remarkable total alopecia. The remaining hairs at the affected area were easily plucked and they were in typical anagen phase. Microscopically the roots were pigmented having anagen features.

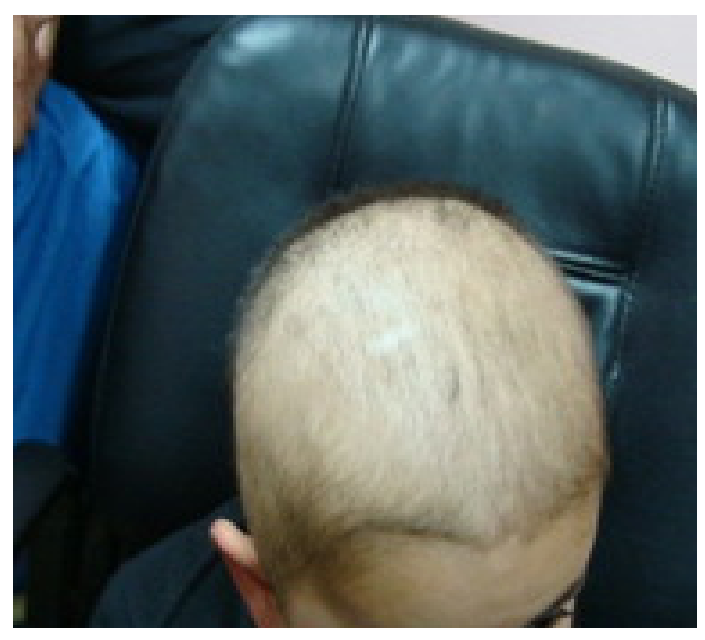

Figure 1. Anagen hair loss 


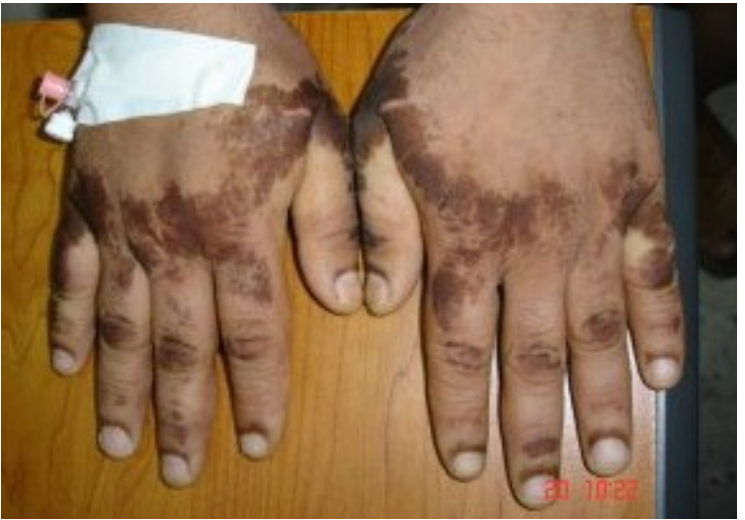

Figure 2. A dermatitis-like picture with ecchymotic dusky red color

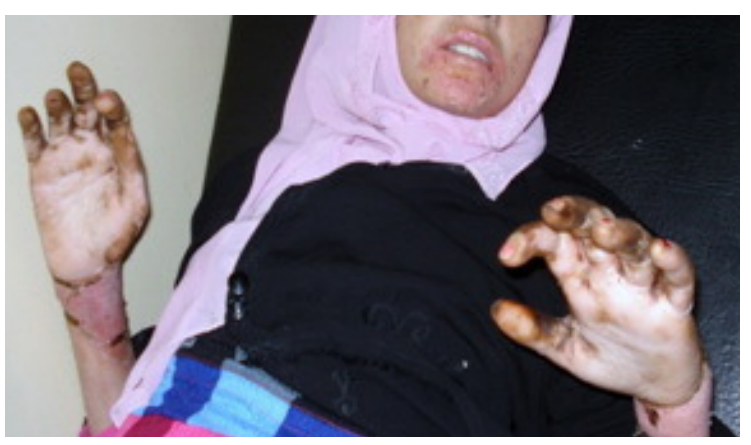

Figure 3._Ecchymotic dusky red color that covered the face especially around the mouth and the limbs

While erythematous lesions appeared in all patients in the first week, presenting as a dermatitislike picture with ecchymotic dusky red color that covered the face especially around the mouth and the limbs mainly the dorsa of both hands simulating horse shoe appearance and that of zinc deficiency or pellagra like (Figure 2,3). Acneiform rash of the face was also presented in two patients.

The neurological findings were observed in $50 \%$ of patients of the second group as peripheral neuropathy with marked leg and foot tenderness and paraesthesia which developed with in 2 to 4 days of thallium intoxication. Muscular weakness was noted in most of those patients especially of the lower limbs, with variable severity.

Psychiatric findings were seen in $10 \%$ of patients of the second group mainly in a form of per- sonality changes, depression and apathy while others presented with anxiety and acute agitation.

All patients were given $5 \mathrm{mg} / \mathrm{kg}$ (t.d.s) oral zinc sulfate as they were considered cases of zinc deficiency before the definite diagnosis of thallium poisoning was established. Surprisingly 30 out of 32 cases improved markedly within few days especially regarding the horse shoe like rash on the dorsa of their hands, alopecia and neuromuscular involvement. The patients were kept on this treatment for two weeks with no relapse was reported after that, whereas the remaining two cases of the second group who presented later with severe neurological symptoms and in spite of the dramatic response to the oral zinc sulfate regarding their dermatological symptoms, and after establishing the diagnosis they received adjuvant activated charcoal and Prussian blue, those two patients deteriorated and died due to respiratory failure.

\section{DISCUSSION}

The International Program on Chemical Safety (IPCS) of the World Health Organization (1996) has produced a detailed Environmental Health Criteria Monograph on thallium. The monograph concluded that in the general population, the total intake of thallium has been estimated to be less than 5 microgram per day, mostly from foodstuffs, and that this does not constitute a threat to health. ${ }^{1}$

Thallium is commonly used in Iraq as rat poison but the medical literatures was lacking of any recording of sporadic cases or outbreak poisoning.

Most recently as a result of occupation and war, thallium was used as a chemical poison for mass killing mainly for political reasons as in February 2008 outbreak of thallium poisoning occurred mainly among members of Iraqi air force club where some of their children were poisoned by cake laced with thallium and two of the children died. ${ }^{9}$ Thereafter followed by a sequences of 22 cases who were seen by the poisoning consultation 
center, where five cases had the skin and neurological finding were the dominant pictures. ${ }^{14}$

In our study two out breaks of the poisoning were reported at 2009 and 2010 showed that the skin manifestations were very characteristic of thallium poisoning, especially the severe anagen alopecia and dermatitis like pictures. These features had been similarly reported by other studies ${ }^{14}$ and are so characteristic that can lead into right diagnosis. Other diagnoses that might be mistaken with thallium poisoning are acquired zinc deficiency, pellagra and erythema multiforme. ${ }^{14}$

The similarities of skin and hair manifestations between thallium poisoning and that of pellagra and/or zinc deficiency, with dramatic improvement of all cases after treatment with oral zinc sulfate, raise a question if thallium poisoning interacts in away or another with zinc or niacin metabolism, so causing their deficiency, resulting in clinical features simulating that of these elements deficiency. These possibilities may explain why a zinc supplement is helpful in the treatment of thallium poisoning, so that these points should be considered in any further studies.

On the other hands the dramatic improvement of all cases after treatment with oral zinc sulfate necessitate further studies to identifying the mechanism of it's action including animal study that is strongly recommended.

Because of thallium is tasteless and colorless it can be used as chemical weapons especially when it is freely available in the market. So thallium poisoning seems to appear more in wars and in poor political and security situations like in Iraq after 2003. Therefore any patient with sudden onset of hair fall of anagen type with skin and neurological problems may be diagnosed as thallium poisoning unless proved otherwise.

In conclusion outbreak of thallium poisoning is occurring in Iraq which may be lethal to human being as a result of accidental ingestion or for criminal purposes. It gives a characteristic skin and hair manifestation that are very helpful for diagnosis. We suggested that thallium in rat poisoning can be considered as a chemical weapon and should be banned.

\section{REFERENCES}

1. John Peter AL, Viraraghavan T. Thallium: a review of public health and environmental concerns. Environment International 2005:31:493-501.

2. Desenclos JC, Wilder MH, Coppenger GW, Sherin K, Tiller R, Vanhook RM. Thallium poisoning: an outbreak in Florida 1988. South Med J 1992;85:1203-1206.

3. Meggs WJ, Hoffman RS, Shin RD, Weisman RS, Goldfrank LR. Thallium poisoning from maliciously contaminated food. J Toxicol Clin Toxicol 1994;32:723-730.

4. Galvan-Arzate S, Santamaria A. Thallium toxicity. Toxicol Lett 1998;99:1-13.

5. Baldwin DR, Marshall WJ. Heavy metal poisoning and its laboratory investigation. Annals of Clinical Biochemistry 1999;36:267-300.

6. Insley BM, Grufferman S, Ayliffe HE. Thallium poisoning in cocaine abusers. Am J Emerg Med 1986;4:545-548.

7. Moore D, House I, Dixon A. Thallium poisoning: diagnosis may be elusive but alopecia is the clue. BMJ 1993;306:1527-1529.

8. Rusyniak DE, Furbee RB, Kirk MA. Thallium and arsenic poisoning in a small Midwestern town. Ann Emerg Med 2002;39:307-311.

9. BBC News/Middle East/Poison cake kills Iraqi children (Iraqi Air Force Club). http://news.bbc.co.uk/2/hi/middle_east/7237086.stm.

10. Kuo HC, Huang CC, Tsai YT, Chu CC, Hsieh ST, Chu NS. Acute painful neuropathy in thallium poisoning. Neurology 2005;65:302-304.

11. Feldman J, Levisohn DR. Acute alopecia: clue to thallium toxicity. Pediatr Dermatol 1993;10:29-31.

12. Prick JJG. Thallium poisoning: Vinken DJ, Bruyn GW, eds. Handbook of clinical neurology: intoxications of the nervous system. North-Holland Pub Co., Amsterdam 1979;36:239-278.

13. Ching-I Lu, Chin-Chang H, Ya-Ching C, et al. Short-term Thallium Intoxication. Arch Dermatol 2007;143:93-98.

14. Sharquie KE. No man is an island, Thallium poisoning with skin manifestations. Virtual Grand Round in Dermatology 2.0, http://vgrd.blogspot.com/2008/04/iraqireality.html?showComment=1209569400000. 